\title{
ÉTICA E JUSTIÇA \\ NUM MUNDO GLOBALIZADO
}

Manfredo Araújo de Oliveira*

SINTESE - O autor examina o fenômeno da globalização, como expressäo de grande valor para o diagnóstico de nossa época. Depois disso, ressalta que não é nos fatos empiricos que se encontrará a resposta sobre a validade dos motivos norteadores da ação humana, mas sim na reflexão do pensamento sobre si mesmo.

PALAVRAS-CHAVE - Ética. Justiça. Globalização.
ABSTRACT - The author discusses the globalization phenomenon, which he regards as a very valuable element in an attempt to provide a diagnosis of the age we live in. Further, he claims that an answer to the question concerning the validity of the motivations which guide human action is not to be found in empirical facts, but in the thinking process' taking itself as an object.

KEY WORDS - Ethics. Justice. Globalization.

\section{Desafios de nosso marco histórico}

A reflexão filosófica sobre a ação humana compreendeu, desde seu início entre os gregos, que seus princípios são prescritivos precisamente na medida em que devem procurar uma tradução na vida humana que é sempre uma vida sóciohistórica, marcada por uma determinada tradição cultural. Assim, a própria reflexão parte da "situação mundana" em que os seres humanos se situam e retorna a ela no sentido de delinear os imperativos históricos em relação a esta situação de tal modo que repor hoje a pergunta por ética e justiça implica, em primeiro lugar, perguntar-se pela configuração básica da situação sócio-histórica em que estamos inseridos e que constitui o pano de fundo de nossas perguntas.

Alguns fatos chamam imediatamente a atenção sobretudo quando se tem na memória nossa situação epocal nas décadas anteriores: por exemplo, o fato de, mesmo nos países ricos, milhöes de pessoas sobreviverem na base dos auxílios assistenciais dos estados e de milhões viverem abaixo dos limites oficiais de pobreza; ${ }^{1}$ há uma aceleração do desemprego, ${ }^{2}$ mas mais rapidamente ainda crescem

* Professor da UFC (Universidade Federal do Ceará).

- O presidente do Banco Mundial num discurso perante a junta de governadores do banco em Washington, no final de setembro de 1999, como noticiado pela imprensa intemacional, chamou 
os ganhos com ações e os lucros das empresas; o abismo entre norte e sul aumenta $^{3}$ e explodem conflitos culturais entre o ocidente secularizado e o mundo islâmico teocrático, reações etnocêntricas de populações nacionais contra o estrangeiro, contra os que têm outras crenças, outra cor, contra deficientes e grupos marginais precisamente num momento em que as migrações crescentes provocam a convivência de populações étnica, religiosa e culturalmente diferentes. As sociedades européias, por exemplo, estão a caminho de se tornarem sociedades multiculturais o que levanta o desafio da criação de estruturas de convivência política que possibilitem a coexistência igualitária de formas de vida diferenciadas étnica, lingüística e religiosamente. Neste contexto de heterogeneidade cultural, está em ascensão um novo individualismo que se contrapõe à atitude coletivista das esquerdas tradicionais na medida em que as massas assimilaram valores próprios da sociedade capitalista como a competição e a realização pessoal uma vez que mercados globalizados, consumo de massa, comunicação de massa e turismo de massa possibilitaram a difusão mundial dos produtos da cultura de massa proveniente sobretudo dos Estados Unidos: os mesmos bens e estilos de consumo, os mesmos filmes, programas de televisão e as mesmas músicas se espalham pelo mundo. Emergem igualmente processos que destroem a solidariedade, sobretudo quando está em jogo a questão da redistribuição, e que podem conduzir à fragmentação política. ${ }^{4}$

Tudo indica, como diz Habermas, ${ }^{5}$ que as democracias de massa do estado de bem-estar social se encontram no fim de um desenvolvimento que começou com o estado nacional originado das revoluções burguesas da modernidade. Para ele, o conteúdo contrafático daquilo que Rousseau ${ }^{6}$ e Kant conceptualizaram como "autonomia republicana"” encontrou sua realização em sociedades constituídas como estados nacionais. O Estado territorial, a nação e uma economia constituída em fronteiras nacionais formaram, então, uma constelação histórica em que o processo democrático pode encontrar uma configuração institucional mais ou menos convincente. A idéia fundamental da democracia moderna - que uma sociedade pode atuar sobre si mesma enquanto um todo - até agora só encontrou realização no seio do estado nacional. O que caracteriza nossa época, para Habermas, é que precisamente esta constelação histórica está sendo posta em questão por aquilo

a atenção, citando o relatório do banco, para a crescente pauperização: atualmente, 1,5 bilhão de pessoas sobrevivem com o equivalente a menos de um dólar por dia. Cf.: RIFKIN, J. O fim dos Empregos. São Paulo, 1995.

3 Cf.: HEINRICHS, J./KREYE, A. Die neue internationale Arbeitsteilung. Strukturelle Arbeitslosigkeit in den Industrieländern und die Industrialisierung der Entwicklungsländer. Hamburg, 1977.

- Cf.: HABERMAS, J. Die postnationale Konstellation und die Zukunft der Demokratie, in: Die postnationale Konstellation. Politische Essays, Frankfurt am Main, 1998, p. 111.

- Cf.: HABERMAS, J. Die postnationale Konstellation, op. cit., p. 94.

- Cf.: OLIVEIRA, R. J. de. A utopia rousseauísta, in: Utopia e razão pensando a formação éticopolítica do homem contemporâneo. Rio de Janeiro, 1998, p.71-97.

- Cf.: HABERMAS, J. Die Einbeziehung des Anderen. Studien zur politischen Theorie, Frankfurt am Main, 1996, p. 89 e ss. 
que se convencionou chamar de "globalização" que, por sua vez, para Höffe ${ }^{9}$ constitui a nova palavra-chave da filosofia política. ${ }^{10} \mathrm{~A}$ palavra é marcada por emoções contraditórias, em parte esperanças, em parte medo, mas, quando se consegue atribuir-lhe um sentido preciso, ela pode ter um grande valor para 0 diagnóstico de nossa época. Ela tem, acima de tudo, o mérito de explicitar o grande desafio de nossa formação sócio-histórica.

Em última instância, a globalização ${ }^{11}$ significa, do ponto de vista econômico e político, uma forma nova de acumulação e regulação do capital, que então se tornou, no sentido pleno, um sistema econômico mundial. ${ }^{12}$ Ela substitui o sistema de Bretton Woods, que significou um regime internacional da economia na medida em que, através de um regime cambial fixo e da ação de instituições como o BanCo Mundial e o FMI, foi possível encontrar um equilibrio entre políticas econômicas nacionais e regras do comércio mundial liberalizado. ${ }^{13}$ Este sistema foi abandonado no início dos anos 70, surgindo, em seu lugar, um "liberalismo transnacio-

- Para Höffe, trata-se do desafio fundamental de nossa época, mas não de sua característica única, pois há várias contra-tendências: por exemplo, há um movimento de regionalização, que condiciona a própria globalização econômica. Hả também a fragmentação das megacidades em grupos étnicos e culturais separados entre si, o crescimento, nas democracias jovens, de sentimentos nacionalistas e ainda o fato, que não pode ser esquecido, da existência de linguas, costumes e religiōes diferentes (Cf.: HÖFFE, O. Demokratie im Zeitalter der Globalisierung, München, 1999, p. 20-21). Cf.: Höffe, op. cit., p. 13.

10 Para Höffe, desde os iniciadores da filosofia do Estado e da filosofia do direito, Platão e Aristóteles, a filosofia politica sempre teve como referência empirica as comunidades particulares. A globalização põe a filosofia politica diante de desafios desconhecidos pelo pensamento da tradição (Cf.: Höffe, op. cit., p. 14).

"L É, em geral, consenso, que experimentamos, no momento presente, um crescimento drástico das atividades internacionais, sobretudo, embora não exclusivamente, dos fluxos internacionais de mercadorias e de capital. Formaram-se, segundo Perraton J./Goldblatt D./Held D./McGrew A., um grupo que desenvolveu a pesquisa : Globalisation and Advanced Industrial State na Open University em Londres (Cf.: Die Globalisienung der Wirtschaft, in: BECK, U.(org.), Politik und Globalisierung, Frankfurt am Main, 1998, p. 134-168), dois grupos de intérpretes : para uns este desenvolvimento conduz ao desaparecimento dos estados nacionais e para outros nada há de novo, porque não existe propriamente um sistema global. A respeito do segundo grupo cf.: Hirst P./Thompson G., Globalizaçäo em questão, Petrópolis, 1998; Globalisierung? Intemationale Wirtschaftsbeziehungen, Nationalökonomien und die Formierung von Handelnsblöcken, in: Beck (org.), op. cit., 1998, p. 85-133. J.Habermas e $\mathrm{O}$ Höffe se põem para além desta contraposiçẫo na medida em que não afirmam propriamente o desaparecimento dos estados nacionais, mas sua inserção num contexto novo, que muda radicalmente as condições de contorno em que se formaram e se desenvolveram as democracias modernas.

12 Cf.: OLIVEIRA, M. A. De. Die Globalisierung und die Problematik der Dritten Welt: Ethische Herausforderung, in: Fornet-Betancourt R. (org.), Armut im Spannungsfeld zwischen Globalisierung und dem Recht auf eigene Kultur: Dokumentation des VI. Internationalen Seminars des philosophischen Dialogsprogramms, Frankfurt am Main, 1998, p. 155-185. FURTADO, C., O capitalismo Global, 4. ed., Rio de Janeiro, 2000.

Cf.: BRAVERMAN, H., Trabalho e capital monopolista, Rio de Janeiro, 1980. KEMP, T., The climax of capitalism, London, 1990. Habermas, op. cit., p. 119. SAMPAIO Jr., P. de A., Entre a Naçäo e a Barbánie. Os dilemas do capitalismo dependente, Petrópolis, 1999, p. 17: "O fim do ciclo de difusão da Segunda Revolução Industrial rompeu os parâmetros técnicos e econômicos que durante o pósguerra haviam sustentado as dinâmicas virtuosas responsáveis pelo progressivo aumento dos salários reais e pela expansão do estado de bem-estar social". 

ação cada vez mais independente do espaço dos estados nacionais ${ }^{15}$.

A globalização é o resultado de opções políticas determinadas, mas tem inúmeros pressupostos ${ }^{16}$ entre os quais certamente um dos mais importantes é a nova revolução tecnológica ${ }^{17}$ que fez da ciência e da técnica as forças impulsionadoras do novo paradigma de produção industrial ${ }^{18} \mathrm{e}$, em última análise, da nova forma de

${ }^{3}$ Cf.: DUCHROW, U., Alternativen zur kapitalistischen Weltwirtschaft. Biblische Eninnerung und politische Ansätze zur Überwindung einer lebensdrohenden Ökonomie, Mainz, 1994. A respeito das conseqüências deste processo no Brasil, cf.: GONÇALVES, R. Vulnerabilidade ampliada, Rio de Janeiro, 1999.

15 Isto provocou a retomada do debate sobre a relação entre poder público e desenvolvimento econômico. Cf.: FIORI, J. L. (org.), Estados e Moedas no desenvolvimento das nações, 2. ed., Petrópolis, 1999. Como também do impacto deste processo nos paises em desenvolvimento. Cf.: FURTADO, C., A nova dependência, Rio de Janeiro, 1982, p. 132: "Temos que interrogar-nos se os povos da Periferia vão desempenhar um papel central na construção da própria história, ou se permanecerão como espectadores enquanto o processo de transnacionalização define o lugar que a cada um cabe ocupar na imensa engrenagem que promete ser a economia globalizada do futuro".

16 A respeito de pressupostos culturais cf.: HOBSBAWN, E., Era dos extremos. O breve século XX(1914-1991), São Paulo, 1997, p. 314-336. MARDONES, J. M., Capitalismo y religión. La religión politica neoconservadora, Santander, 1991.

17 Cf.: PIORE, M. J./SABEL C. F, The second industrial divide - possibilities for prosperity, New York, 1984. Maddison A, Dynamic forces in capitalist development, Oxford, 1991. Uma interpretação puramente econômica da globalização, segundo Höffe, é obra comum dos liberais ortodoxos e dos marxistas que só enxergam no mundo a ação de forças econômicas. Ora, para ele, nem mesmo as mudanças econômicas têm causas puramente econômicas, pois elas dependem também de decisões politicas e de renovações tecnológicas. Ele insiste numa interpretação não exclusivamente econômica da globalização. Cf.: Höffe, op. cit., p. 15. O pensamento liberal privilegia os aspectos econômicos e interpreta a globalização como uma conseqüência necessária da revolução tecnológica recente, que, aliada à expansão dos mercados, derrubou as fronteiras territoriais e eliminou os projetos econômicos nacionais. A afirmação mais polêmica desta interpretação é que a própria globalização econômica promoveria uma homogeneização progressiva da riqueza e do desenvolvimento através da mediação do livre comércio e da liberdade completa de circulação dos capitais privados, o que conduziria a humanidade a um govemo global e a uma democracia cosmopolita. Para uma critica destas teses cf.: SANTOS, M., Por uma outra globalizaçăo - Do pensamento único à consciência universal, São Paulo, 1999. Para C. Furtado a difusão dos valores desta revolução tecnológica aprofundou o grau de dependência cultural das regiöes periféricas: os avanços nas áreas de comunicação e de transporte exacerbam a tendência ao mimetismo cultural nas classes média e alta dos paises periféricos. Trata-se de copiar os padrões de consumo e comportamento vindos do centro hegemônico. Cf.: FURTADO, C., A nova dependência, Rio de Janeiro, 1982, p. 132. Além se difundiu a idéia de que se trata de um processo inexorável. Cf.: FURTADO, C., O capitalismo global, op. cit., p. 26: "Neste fim de século prevalece a tese de que o processo de globalização dos mercados há de se impor no mundo todo, independentemente da política que este ou aquele país venha a seguir. Trata-se de um imperativo tecnológico, semelhante ao que comandou o processo de industrializaçăo que moldou a sociedade moderna nos dois últimos séculos".

18 Por esta razão se fala hoje da passagem de uma sociedade de mercadorias para uma "sociedade da informação". Cf.: DRUCKER, P. F., La sociedad poscapitalista, Buenos Aires, 1990; Las nuevas realidades, Buenos Aires, 1990. Para Habermas, a massa de trabalhadores que, durante séculos, trabalhou na agricultura, migrou , na modemidade, primeiramente para a indústria e depois para os serviços. Hoje surge um "quarto setor" de campos de atividades baseados no saber, que dependem da abundância de novas informaçōes, em última instância, da pesquisa e da inovação. Estas, por sua vez, dependem da "revolução do sistema educativo", que levou a uma ampliaçåo drástica dos níveís secundário e superior do sistema de educação. Cf. : HABERMAS, J., Aus Katastrophen lemen? Ein zeitdiagnostischer Rückblick auf das kurze 20. Jahrhundert, in: Die postnationale Konstellation, 
acumulação, a "acumulação flexível" em que ocorre, por um lado, um aumento muito grande da produtividade do trabalho acompanhada de uma mudança significativa nas relações entre o capital e o trabalho e, por outro, uma competitividade exacerbada a nivel internacional ${ }^{19}$ uma vez que as empresas säo forçadas, no mercado aberto, a aumentar sempre mais sua produtividade e diminuir seus custos sobretudo através da diminuição da mão de obra. ${ }^{20}$ Esta nova tecnologia se radica em mecanismos regulados por computadores, que são capazes de programar todo o processo de automatização de tal modo que a eletromecânica se constitui o fundamento do novo processo produtivo. Numa palavra, o eixo central deste novo processo produtivo é a tecnologia da informação, que transformou, profundamente, através das indústrias da comunicação, nossas experiências de tempo e espaço $^{21}$ e as estruturas das relações entre as culturas.

A informática, a nova automação, a biotecnologia, a intervenção genética, os novos materiais e as novas formas de administração das empresas provocaram reestruturações importantes nas relações entre as nações e nas relações sociais fundamentais. As duas de maiores conseqüências são, certamente, a reorganiza-

op. cit., p. 67. Além disto, em nossas sociedades complexas, cada especialista é leigo em relação a todos os outros especialistas de tal modo que somos todos, de certo modo, marcados por uma "segunda ingenuidade" ( na expressão de $\mathrm{M}$. Weber) na medida em que temos que ter familiaridade com um conjunto de aparelhos eletrônicos, cuja técnica não captamos e que constituem a acumulação de saber de muitos gerações de cientistas (Cf.: Habermas, op. cit., p. 69-70).

$\mathrm{O}$ que, segundo C. Furtado, tem levado a uma desarticulação dos mecanismos que davam coerência aos sistemas econômicos nacionais e conseqüentemente a aumentar o hiato que separa as economias centrais das economias periféricas (Cf.: FURTADO, C., Globalizaçăo das estruturas econômicas e identidade nacional, in: Estudos Avançados, São Paulo, v. 6, n. 16, 1992, p. 55-64).

$\mathrm{O}$ que tem provocado uma diminuiçăo dos trabalhadores sindicalizados e sobretudo da força dos sindicatos no contexto politico atual. Técnicas de relações humanas procuram facilitar a integração dos trabalhadores na empresa e se proclama o desaparecimento dos conflitos sociais. Para Höffe, esta competitividade se instalou hoje em todos os campos da vida humana, na ciência e na cultura, mesmo na linguagem e na religião. Cf.: Höffe, p. 19. De modo geral, isto é, com exceção da África abaixo do Saara e da China, o setor agránio foi fortemente mecanizado, o que levou a uma enorme diminuição do contingente de trabalhadores na agricultura e uma transformação radical nas relaçôes campo-cidade, portanto a uma ruptura grande com as formas de vida predominantes no passado, inclusive a uma profunda transformação na vida urbana. Nova York está a grande distância do que eram Paris e Londres no século passado e as grandes cidades de hoje, México, Tóquio, Calcutá, São Paulo, Cairo, Seul e Xangai rompem com as dimensões convencionais da "cidade" que conhecíamos (Cf. : Habermas, Aus den Katastrophen lernen?, op. cit., p. 68).

${ }^{21}$ Há um processo de construção de uma rede mundial de informaçōes e meios de transporte, que diminuem drasticamente as distâncias espaciais e fazem com que os eventos sejam praticamente conhecidos e assimilados instantaneamente. Trata-se de uma globalização cultural, que, de alguma maneira, pode ter efeitos democratizantes: na rede mundial eletrônica são tratados igualmente todos os lugares, todas as pessoas, empresas e estados. Além disto tem também efeitos ecológicos: quem viaja com a Internet, em lugar de carro ou avião, economiza energia e diminui a poluição do meio ambiente Cf.: Höffe, op. cit., p. 18-19. Para Habermas, há aqui um deslocamento de grandes conseqüências para o futuro: ao invés de corpos reunidos em grandes manifestaçōes temos hoje a "inclusão simbólica" da consciência de muitos em redes de comunicação cada vez mais amplas. A massa concentrada se transforma no público disperso dos meios de comunicação. Esta unificação eletrônica dos indivíduos está tomando anacrônicos os movimentos das massas nas ruas e praças (Cf. : Habermas, Aus den Katastrophen lemen?, op. cit., p. 67). 
ção do processo produtivo ${ }^{22}$ e os enormes impactos no sistema de emprego na medida em que a produtividade do trabalho se fez o motor de todo este desenvolvimento e o desemprego se tornou fenômeno estrutural, ${ }^{23}$ que constitui provavelmente a questão social mais grave do novo contexto societário. Por outro lado, o efeito visivel destas mudanças mais claro é o processo de financeirização do capitalismo: ${ }^{24}$ não só há uma aceleração dos movimentos do capital através da unificação eletrônica dos mercados financeiros, mas sobretudo a tendência da autonomização dos circuitos financeiros, que desenvolvem uma dinâmica própria independente da economia real. ${ }^{25}$ A produção deixa então de ser a função econômica principal e os mercados financeiros transnacionais assumem a condução de todo o processo econômico de tal modo que a valorização do dinheiro se torna o grande objetivo e o mecanismo fundamental de regência de toda a vida econômica, social e política ${ }^{26}$ assim que a estabilização da moeda se transforma no ponto central das políticas públicas. O resultado mais imediato é que as bolsas internacionais se transformam em mecanismos de avaliação de toda a política econômica nacional. Para Habermas o paradoxo desta situação consiste no fato de que nunca políticas que estimulam o crescimento foram tão necessánias exatamente num contexto em que elas se tornaram praticamente impossiveis. ${ }^{27}$

Pode-se falar, em relação ao capitalismo estatalmente organizado a partir de 1930, de um processo de "politização" da economia: $:^{28}$ surgiram economias mistas

2. Ocorre hoje uma enorme descentralização do processo de trabalho, que se divide em dois setores: o núcleo, com tecnologia de ponta e trabalhadores pouco numerosos e altamente qualificados, os artesãos eletrônicos (Cf.: GORZ, A., Capitalisme, Socialisme, Écologie, Paris, 1991) e, de outro lado, uma rede enorme de pequenas e micro empresas que trabalham por terceirização a partir de encomendas das empresas centrais (Cf: HARVEY, D., A transformaçāo politico-econômica do capitalismo do final do século XX, in: Condição pós-moderna. Uma pesquisa sobre as origens da mudança cultural, São Paulo, 1993, p. 115 e ss).

*3 O que provocou no âmbito da sociologia uma discussâo sobre a centralidade da categoria trabalho para a compreensão das sociedades contemporâneas (Cf.: OFFE, Cl., "Arbeitsgesellschaft". Sturkturprobleme und Zukunftsperspektiven, Frankfurt am Main/New York, 1984. TEIXEIRA, F.J.S./OLIVEIRA, M.A de (Orgs.), Neoliberalismo e Reestruturação Produtiva. As novas determinaçōes do mundo do trabalho, São Paulo/Fortaleza, 1996). Para Höffe, esta situação faz com que a globalização crie, na vida humana, uma comunidade de miséria e sofrimento. Há hoje um desrespeito escandaloso dos direitos humanos, guerras civis, corrupção e desgoverno, fome, pobreza, subdesenvolvimento econômico, cultural e político, grandes movimentos migratórios em parte de fugitivos (Cf.: Höffe, op. cit., p. 20).

${ }^{24}$ Cf.: BRAGA, J. C. A finaceinzação da riqueza. in: Economia e Sociedade, n. 2, 1993, p. 25-58. CHESNAIS, F., A mundialização do capital, São Paulo, 1996.

25 Cf: Habermas, Die postantionale Konstellation, op. cit., p. 103.

Cf.: ALTVATER, E. Die Zukunft des Marktes. Ein Essay über die Regulation von Geld und Natur nach dem Scheitern des "real existierenden Sozialismus", Münster, 1991.

z É neste sentido que J.Neyer afirma que o keynesianismo não funciona hoje mais a nível de um só pais. Cf:: NEYER, J., Spiel ohne Grenzen, Marburg, 1996.

29 Estabeleceu-se uma regulação macroeconômica da sociedade através de políticas tributárias, monetárias e sociais, sobretudo no campo da previdência social, das politicas de moradia, da escola, das aposentadorias e do controle da demanda. Além disto, foram criados mecanismos para regular as relações entre empresários e trabalhadores, que possibilitaram acordos a respeito da distribuição das riquezas produzidas, cujo objetivo era combinar o máximo de produtividade e intensidade do trabalho com salários diretos e indiretos ascendentes (Cf.: Oliveira, op. cit., p. 158). 
na medida em que o Estado tinha, à sua disposição, através da apropriação de uma boa parte do produto social, um espaço para medidas distributivas e subvenções e para implementar políticas sociais eficientes na esfera da infra-estrutura e do emprego. Ele podia intervir nas condições de contorno de produção e distribuição com a finalidade de alcançar crescimento, estabilidade de preços e emprego pleno, o que se traduzia numa política social distributiva através dos diferentes projetos no âmbito do mercado de trabalho, da familia e da educação, da proteção à natureza e do planejamento das cidades. $\mathrm{O}$ objetivo era produzir aqueles bens públicos e as condições sociais, naturais e culturais de vida que conservavam a urbanidade, o espaço público de uma civilização frente ao risco da destruição. ${ }^{29}$ Numa palavra, o Estado regulador podia conseguir, ao mesmo tempo, estimular a dinâmica econômica e a integração social. ${ }^{30}$ Isto tinha um pressuposto fundamental: a suposição de que os cidadãos reunidos de uma comunidade democrática podem configurar seu contexto social. Assim, o conceito jurídico de autolegislação adquiriu uma dimensão política e se tornou um conceito de uma sociedade que intervém sobre si mesma democraticamente. Isto gerou no ocidente as democracias de massa dos estados de bem-estar social. ${ }^{31}$

Hoje o que está ocorrendo é uma substituição da política pelo mercado ${ }^{32}$ na condução dos processos sociais, ou seja, está em andamento um processo de "mercantilização" da vida social como um todo, ${ }^{33}$ o que significa dizer que uma economia globalizada se subtrai à ação do estado regulador e submete ao mercado todos os fatores da produção num processo acelerado de internacionalização de todos os mercados ${ }^{34}$ e a contraposição radical entre metas econômicas e fins sociais e políticos. "Quanto mais as empresas se globalizam, mais escapam da ação reguladora do Estado, mais tendem a se apoiar nos mercados externos para cres-

\footnotetext{
Cf.: Habermas, Die postantionale Konstellation, op. cit., p. 118.

Cf.: Habermas J, Aus Katastrophen lemen?, op. cit., p. 80.

Cf.: Habermas, Die postnationale Konstellation, op. cit., p. 93-94.

${ }_{32}$ Dinheiro substitui poder na expressảo de Habermas. Ora só o poder pode ser democratizado, o dinheiro não. $\mathrm{Na}$ medida então em que o dinheiro se torna o mecanismo de coordenação da vida social, a democracia se torna impossivel (Cf.: Habermas, Die postnationale Konstellation, op. cit., p. 119-120).
}

33 Habermas fala de uma mercantilização brutal do mundo vivido (Cf.: Habermas J., op. cit., pg. 133). Höffe, por sua vez, chama atenção para o fato de que a globalização não é um fenômeno natural, mas fruto de decisões humanas. Assim, os acordos de Bretton Woods (1944), o Acordo Geral de comércio e alfândega (GATT, 1947) e a Organização para a cooperação econômica européia (OEEC, 1948, depois OECD, 1960) foram as condiçōes para a liberalização e a desregulamentação dos mercados de bens e de finanças. A globalização, que se seguiu a isto, foi acelerada pela intervenção de outros fatores, entre os quais tem papel fundamental a nova revolução tecnológica (Cf.: Höffe, op. cit., p. 18).

Ou seja, para Habermas, uma tentativa sistemática de desconstrução do estado social através de uma política econômica orientada na oferta e na eliminação dos mecanismos que permitiam a intervenção estatal nas condições de contorno do processo econômico. O resultado é o reaparecimento de tendências de crise e desigualdades, cada vez maiores, que geram exclusões e ameaçam a capacidade de integração de uma sociedade liberal e conseqüentemente provocam um processo de destruição da solidariedade social que só pode ter como conseqüência o desaparecimento de uma cultura política que constituia a base universalistica de sociedades democraticamente reguladas (Cf.: Habermas, op. cit., p. 80-81). 
cer. Ao mesmo tempo, as iniciativas dos empresários tendem a fugir do controle das instâncias políticas". ${ }^{35}$ Agora as forças do mercado se transformam em forças reguladoras da sociedade e do Estado e o primado da produtividade e do lucro se tornou a mediação inevitável das relações sociais e políticas. ${ }^{36}$

O primeiro efeito deste processo ${ }^{37}$ se mostra no fato de que o estado nacional perde, cada vez mais, sua capacidade de captar impostos, estimular o crescimento e com isto assegurar as bases de sua legitimação, pois a base fiscal da política social se torna cada vez menor como, por outro lado, cresce a incapacidade de regulação macroeconômica sem que se descubra a nível internacional um equivalente funcional, o que significa que o estado nacional é limitado em seu espaço de ação $0^{38}$ e inseguro em sua identidade coletiva. ${ }^{39}$ Com uma sociedade mundial interdependente muito raramente há congruência entre participantes e concernidos nas decisōes estatais. Para além dos estados nacionais formam-se blocos militares ou econômicos, que dão origem a outras fronteiras com quase a mesma importância que as fronteiras territoriais : emerge assim um governar para além dos estados nacionais que, de algum modo, compensa a perda de capacidade de ação dos estados nacionais em determinados campos. ${ }^{40}$ Além disto, cresceu o número das organizações governamentais internacionais e aumentou muito a influência de organizações não governamentais como por exemplo a Worldwide Fund for Nature, a Greenpeace e a Amnesty International. No entanto, certamente há, cada vez

35 Cf.: Furtado, O Capitalismo Global, op. cit., p. 29. No caso da América Latina, este processo leva a uma pergunta fundamental: até quando pode acreditar na democracia uma sociedade que vê crescer aceleradamente a riqueza financeira ao mesmo tempo que aumentam o desemprego e a exclusão social? Cf. a respeito: Santos, op. cit.

36 Cf.: GDDENS, A, A Terceira Via. Reflexōes sobre o impasse politico atual e o futuro da SocialDemocracia, Rio de Janeiro, 1999. Furtado, O Capitalismo Globalizado, op. cit., p. 29: "Em suma, o tripé que sustentou o sistema de poder dos Estados nacionais está evidentemente abalado, em prejuizo das massas trabalhadoras organizadas e em proveito das empresas que controlam as inovações tecnológicas".

T.: SCHARP, F. W., Demokratie in der transnationalen Politik, in: Beck., op. cit., p. 228-253, sobretudo 243 e ss. A respeito do caso do Brasil, cf.: Singer, A dominação financeira, in: Folha de São Paulo, 5/04/00, p. 2-2: "As politicas do governo FHC exibem uma clara ordem de prioridades: em primeiro lugar vêm as metas inflacionárias, que pautam a politica do Banco Central; em seguida, o ajuste fiscal, negociado primeiro com o FMI e só mais tarde com o Congresso; e depois as políticas agrícola, industrial, de comércio externo, de pesquisa científica e tecnológica etc. As políticas de geração de trabalho e renda, de amparo à pequena empresa e à agricultura familiar, de reforma agrária de educação, de saúde, de habitação popular etc. vêm na rabeira, constituindo variáveis de ajuste para garantir o cumprimento de metas de inflação e ajuste fiscal."

* Cf.: Furtado C., A construção interrompida, Rio de Janeiro, 1992, p. 35: "Em um país ainda em formação, como é o Brasil, a predominância da lógica as empresas transnacionais na ordenação das atividades econõmicas conduzirá quase que necessariamente a tensões inter-regionais, à exacerbaçâo de rivalidades corporativas e à formação de bolsões de miséria, tudo apontando para a inviabilização do país como projeto nacional."

39 Os Estados nacionais se sentem impotentes também frente a outros movimentos para os quais se tomaram igualmente abertos: criminalidade organizada, comércio de drogas e armas, etc. Além disto, "o desenvolvimento desigual do capitalismo voltou a promover uma brutal concentração espacial do progresso técnico, ampliando o hiato entre desenvolvidos e subdesenvolvidos" (Sampaio Jr., op. cit., p. 22).

4) Cf: HELD, D., Democracy, the Nation State and the Global System, in: HELD, D. (org.), Political Theory Today, Cambridge, 1991, p. 201 e ss. 
mais, acordos a nível internacional, mas estes não vão além de uma integração negativa : se não se consegue nem mesmo chegar a um consenso sobre o imposto Tobin $^{41}$, quanto mais a acordos sobre correções do mercado através de uma coordenação democrática e social nos campos das políticas tributárias, econômicas e sociais tanto mais que a regulação política segue critérios diferentes do que a simples eficácia econômica, o que revela a impossibilidade de substituir pura e simplesmente o poder político pelo mercado. Para Habermas, uma questão, neste contexto muito importante, é que as novas formas de cooperação internacional carecem de legitimação. ${ }^{42}$

O que marca o cenário internacional hoje é uma corrida desesperada para a desregulamentação por parte dos governos nacionais temerosos da fuga de capitais e isto tem conduzido a lucros enormes como também a disparidades gigantescas de renda, a um desemprego crescente e aumento das populações pobres ${ }^{43}$. Para Habermas isto é o resultado de uma ampla renúncia à configuração política das relações sociais e do abandono de pontos de vista normativos ${ }^{44}$ em função de uma adaptação a imperativos sistêmicos, pretensamente inevitáveis. Isto implicaria desembocar num tipo de economicismo que Höffe ${ }^{45}$ denomina "fatalismo econômico" na medida em que atribui à economia a função de decidir não só sobre os meios, mas também sobre os fins da vida social. A política teria como tarefa apenas reagir a estes fins, isto é, ela não tem mais a tarefa de configurar a vida coletiva, mas apenas de ajustar-se à economia, ou seja, de subordinar-se às forças do mercado.

Para Höffe, ${ }^{46}$ esta é apenas uma das dimensões do fenômeno, que numa primeira vista se revela antes como uma ameaça aguda à vida humana e à prosperidade, uma vez que se revela como uma violência que opera a nível mundial. A primeira globalização é a globalização da violência em que 0 arbítrio e o poder tomam o lugar do direito. A humanidade possui hoje a capacidade de um suicídio

4. Cf.: TOBIN, J., A Proposal for Intemational Monetary Reform, in: Eastern Economic Joumal, 4(1978)153-159.

Cf.: Habermas, Die postnationale Konstellation, op. cit., p. 109-110.

Cf.: Bourdieu (org.), A miséna do mundo, Petrópolis, 1997. No caso do Brasil, os analistas acentuam que ele veio aprofundar a situaçâo de miséria de milhôes que não têm acesso à riqueza, à renda, à terra, à educação, à saúde, à moradia, ou seja, aos mínimos sociais inerentes à condição humana. A respeito da inserção do Brasil neste processo cf.: FIORI, J. L., op. cit. BOITO Jr.. A., Política Neoliberal e Sindicalismo no Brasil, São Paulo, 2000. O mais recente relatório do Programa das Nações Unidas para o Desenvolvimento (PNUD) afirma que o Brasil avançou muito pouco na redução da miséria, porque mantém um sistema de grande desigualdade social. Os recursos sociais têm sido direcionados em beneficio da camada mais privilegiada da sociedade brasileira e não para projetos de redução de pobreza inclusive em relação às diferentes regiôes do pais (Cf.: PILATI, R./OSWALD, V., PNUD critica o combate à pobreza no Brasil, in: O Globo, 5 abr. 2000, p. 35).

4. Para ele, as tarefas de um estado social se fundamentavam na dialética da igualdade jurídica e da desigualdade fática e consistiam precisamente em agir com o objetivo de assegurar condições de vida sociais, tecnológicas e ecológicas, que possibilitassem a todos a utilização, em chances igualitárias, dos direitos do cidadão distribuidos em forma igualitária. O intervencionismo social do estado, portanto, se radica nos direitos do ser humano (Cf.: Habermas, op. cit., p. 101). 
coletivo. Além disto existe uma violência que ultrapassa o nivel dos estados: a criminalidade organizada, como o comércio de drogas, de armas e seres humanos e o terrorismo internacional, a destruição do meio ambiente. Num primeiro momento, a globalização cria, portanto, uma comunidade da violência.

Mas há também uma série de fenômenos, segundo Höffe, ${ }^{47}$ que manifestam o lado positivo da globalização: não existe só a comunidade da violência, mas também a "comunidade da cooperação" em diferentes níveis da vida humana com efeitos muitas vezes democratizantes. Assim, por exemplo, a pressão da globalização leva a um questionamento de regimes autocráticos e o desrespeito aos direitos humanos provoca reações fortes a nível mundial. A partir desta base se está formando uma opinião pública mundial, que tem abertura para o mundo e que é fortalecida pela ampliação do direito internacional e do direito dos povos, o que já levou à criação de tribunais internacionais em algumas áreas. Além disto surgem sempre instituições e atividades a nível global, que têm influência importante na vida societária. Tudo isto é sinal que está em formação uma civilização global na forma de uma combinação de uma economia racional com ciência, medicina e técnica $?^{49} \mathrm{Ou}$ antes caminhamos para um luta global de civilizações? ${ }^{49}$ Para alguns intérpretes de nosso tempo, as distinções hoje decisivas não se situam mais entre culturas ou religiões, mas muito mais entre os habitantes do campo e da cidade, entre os que possuem uma formação e os que não a possuem, entre os ricos e os pobres.

De qualquer modo, esta situação constitui o grande desafio, que nos faz repor, em nossa situação sócio-histórica, uma questão fundamental que emerge nas diferentes epocalidades da vida histórica humana: que fazer? Como posicionar-se frente a esta situação? Como configurar a vida humana pessoal e coletiva? Höffe retoma, neste contexto, a problemática que inaugurou a reflexão ético-política do ocidente na República: a forma fundamental de configuração da vida coletiva se efetiva através da mediação do direito e do estado eticamente fundados. A questão se renova hoje a nível mundial: se entre indivíduos e grupos, no lugar do poder, devem reger o direito e a justiça e os dois serem democraticamente organizados, então o mesmo deve valer para as relações entre os estados e a nível global. A grande exigência de nosso tempo não é precisamente uma ordem mundial, democraticamente organizada, radicada na justiça? Consiste então, a resposta da política à globalização na ampliação das democracias singulares na direção de uma democracia mundial ou seja de uma república mundial? Como é possivel, na constelação pós-nacional, conciliar eficiência econômica, liberdade e seguridade social? 0 desafio fundamental de nossa época é, para Habermas, pensar as condi-

\footnotetext{
Cf: Höffe, op. cit., p. 17-18.

Cf.: Höffe, op. cit., p. 29.

Cf.: HUNTINGTON, S. P., The clash of civilizations?, in: Foreign Affairs 72, Cad. 3 (1993) 22-49; The clash of civilizations and the remaking of world order, New York, 1996.
} 
ções de uma política democrática para além do Estado nacional. ${ }^{50}$ Como se legitima uma ética desta "comunidade" mundial?

\section{Historicidade e Metafísica: Filosofia enquanto arqueologia e escatologia transcendentais}

A reflexão ético-política encontra na situação histórica seu ponto de partida: ${ }^{51}$ é aí que o ser humano se experimenta a si mesmo como um ser que tem que ser, isto é, como algo que não encontra sem mais seu ser já dado, mas antes como uma tarefa a se fazer, ${ }^{52}$ o que suscita o desejo de ser. Como seres no mundo nos experimentamos como seres, cuja efetividade não é simplesmente um fato acabado, mas inicialmente apenas uma possibilidade de ser, uma promessa de ser, uma tarefa de ser, uma meta a ser alcançada, um desejo de ser, o que o leva à pergunta: que devo fazer para ser? Esta pergunta brota do seio de nossa finitude, que implica a possibilidade de fracasso em nossa autoconstrução: ${ }^{.53}$ nada nos garante de antemão a efetivação de nossa autoprodução, nosso futuro é aberto e incerto, temos que levar a sério a possibilidade de fracasso. Nossa pergunta inicial mostra assim seu peso histórico: o que aqui está em jogo somos nós mesmos seres fini-

* Cf.: Habermas, Die postnationale Konstellation, op. cit., p. 134.

5. Os comunitaristas têm insistido contra uma reflexâo que parte de um eu abstrato, desvinculado de seu mundo e de sua história, que não corresponde à situação do ser humano enquanto tal que é sempre uma situação histórica, mas ao individuo construido pela modernidade. Cf.: WALZER, M., Thick and Thin: Moral Argument at Home and Abroad, Notre Dame/Ind., 1994. NUSSBAUM, M., The Fragility of Goodness: Luck and Ethics in Greek Tragedy and Philosophy, Cambridge, 1986. KTRATOCHWIL, F. V. Vergesst, Kant! Reflexionen zu Debatte über Ethik und intemationale Politik, in: CHWASZCZA, CH./KERSTING, W. (orgs.), Politische Philosophie der internationalen Beziehungen, Frankfurt am Main, 1998, p. 96-149. W. Desmond descreve com precisão a figura deste indivíduo. Cf.: Desmond, op. cit., p. 283: "O indivíduo ocidental moderno possui muitas das caracteristicas desse eu abstrato: desarraigado do ser, alienado das fontes metafísicas mais profundas de sua própria energia de ser, concentrado no "eu" como um vazio insaciável de apetite calculador, pressentindo o outro como uma ameaça sempre possivel a sua própria autonomia afirmada em alta voz. As fontes dessa abstração incluem as pressuposiçōes ontológicas da ciência/tecnologia e sua tendência a objetivar todo o ser, o ethos capitalista que vê a terra meramente como uma coisa que possui valor de uso, um recurso a ser explorado para fins lucrativos, a burocratização da vida cotidiana e o achatamento dos santuários da intimidade produzido por uma mentalidade empresarial desenfreada."

52. Toda a tradiçâo, desde os gregos, afirmou que a perfeição especifica do ser humano consiste no fato de que ela é construída livremente, cf.: Et. Nic., 6, 1097 b 24-25. É neste sentido que se diz que o ser humano, ser de natureza, está sempre para além da natureza, pois sua auto-realização especifica é uma tarefa ética. Cf.: DESMOND, W., A Filosofia e seus Outros. Modos de ser e de pensar, São Paulo, 2000, p. 288: “[...] o ser ético envolve uma poiesis do próprio eu, o autodesenvolvimento do ser humano na práxis tendo em vista sua perfeição ideal."

6. Cf.: Desmond, op. cit., p. 307: "Por meio dessa questäo mundana surge uma possivel desconfiança metafísica do tempo. Somos finitos e não nos é oferecida nenhuma garantia; nosso ser intermediado não é auto-suficiente; o ser da alteridade situa-se para além de nós mesmos e não pode ser dominado; nossa diferença, não obstante a auto-insistência no que diz respeito a seu próprio ser, nos enche de medo da morte... O desejo humano é inicialmente auto-insistente e afirma seu próprio ser; mas, devido à nossa finitude, a alteridade do ser pode aparecer como uma ameaça a nosso ser..." 
tos, desejosos de ser. ${ }^{54}$ Nosso desejo de ser brota de dentro de nossa situação histórica e sua primeira exigência é a fundamentação da resposta à pergunta sobre o que devemos fazer, pois podemos sempre, em princípio, levantar a questão da validade de todas as nossas representaçōes e de nossos próprios desejos, perguntarmo-nos pela validade de nossas metas e dos meios para atingi-las, o que manifesta um traço característico de nós mesmos: nossa transcendência sobre toda facticidade. A própria pergunta nos arranca da simples facticidade, faz emergir a esfera do possível e manifesta que o ser humano não é um simples produto do seu mundo, de um passado que o carrega e de um presente em que está inserido, mas é capaz de transformar todo e qualquer estímulo que vem do mundo em proposiçōes e afirmá-las ou negá-las, portanto, ele, ser finito e contingente, se eleva sobre o mundo fáctico, inclusive sobre si mesmo, pela possibilidade de perguntar, refletir, julgar, avaliar, e, assim, distanciar-se do mundo e tomar posição sobre ele. O ser humano é um ser com os outros no mundo e ao mesmo tempo acima dele, pois capaz de submeter toda sua experiência à pergunta pela validade, ou seja, ele é o ser da possibilidade da reflexão radical.

Nós, seres humanos do fim deste milênio, temos, a partir de nossa própria situação histórica uma peculiaridade em virtude da especificidade desta situação: não podemos sem mais, para fundamentar nossa resposta, apelar para tradições de vida específicas, ${ }^{56}$ pois, além de elas constituírem nossa facticidade histórica,

54 Cf.: Lima Vaz H. C. de, Escritos de Filosofia V. op. cit., pg. 33: "Com efeito, enquanto imanente à práxis, a Razão prática é normativa por definição. $O$ fim da práxis é a auto-realização do sujeito pela consecução do bem que the é conveniente".

ss Cf.: Oliveira M. A de, A teoria da ação comunicativa e a Teologia, in: Tempo Brasileiro, n. 138: Jürgen Habermas: 70 anos (1999), pg. 110 : “Com a passagem para o pluralismo de cosmovisões, nas sociedades modernas, a religião e o etos nela radicado perdem a função de fundamento público da moral compartilhada por todos". Pode-se considerar as éticas utilitarista (que parte do sujeito que apetece) e kantiana (que tem como principio o eu formal puro) como os dois modelos básicos (uma ética do bem, teleológica e uma ética do dever, deontológica) de uma ética típica da modernidade, que abstrai da comunidade ética formadora do comportamento dos individuos e procura, a partir da reflexâo, estabelecer os principios universais do agir humano. Para Habermas, isto significou um deslocamento radical no procedimento de fundamentação da moral. Cf.: Oliveira, op. cit., p. 112: "A razão passou da natureza e da história da salvação para o espirito dos sujeitos que agem, o que significa dizer que os fundamentos, racionalmente "objetivos", para o julgamento moral e para a ação humana, têm que ser substituídos por fundamentos racionalmente "subjetivos", isto é, trata-se agora de relacionar a ação humana à vontade e à razão dos sujeitos". A respeito da necessidade de uma sintese destas duas posições (ética teleológica e ética deontológica) que seja capaz de abandonar suas fraquezas e recuperar seus méritos cf.: HÖSLE, V., Moral und Politik. Grundlagen einer politischen Ethik für das 21. Jahrhundert, München, 1997, p. 154 e ss. Tanto para Heintel como para Lima Vaz, as tentativas de fundamentação da ética no ocidente podem ser reduzidas a duas posições básicas. Cf. : LIMA VAZ, H. C. de, Escritos de Filosofia V. Introdução à Ética Filasófica 2, São Paulo, 2000, p. 31: "Se deixarmos de lado nesse contexto o modelo empirista que permanece no nivel do universal de facto, temos diante de nós de um lado o modelo platônicoaristotélico, de outro o modelo kantiano... O problema filosófico inicial da razão prática formula-se no campo epistemológico definido por esses dois grandes paradigmas e a eles se reduzem, afinal, os diversos subparadigmas que encontramos na história da Ética, incluindo a Ética contemporânea". Na nota 75 da página 62, Lima Vaz afirma que o que caracteriza a ética clássica é que a obrigação decorre do caráter normativo ou vinculante do Bem objetivo enquanto que a concepção kantiana se funda na necessidade inerente à boa vontade de agir sempre por dever. A sintese entre lei moral e vontade se efetiva pela liberdade. Para Heintel temos também no ocidente dois modelos 
que precisa ser questionada quanto à sua validade, ainda existe o agravante de que vivemos em sociedades multiculturais com formas de vida diferenciadas de tal modo que qualquer tentativa de estabelecimento de normas para nosso agir pode, em principio, levantar a suspeita de absolutização de uma forma cultural específica e de sua imposição às outras.

Neste sentido, nossa própria situação histórica nos aponta para a necessidade de uma reflexão radical $^{56}$ que, sem negar a riqueza das situações humanas específicas, seja capaz de detectar o humano comum do ser humano capaz de orientar nosso ser numa sociedade que se tornou global.

O caminho já foi delineado: como toda facticidade pode ser questionada em relação a sua validade não pode ser nos fatos empíricos que vamos encontrar a resposta sobre a validade dos motivos que possam reger nossas ações no mundo, nem mesmo nos fatos das intuições, que, em princípio, podem ser sempre negadas. A esfera normativa se revela assim como sendo autônoma em relação a qualquer facticidade, ${ }^{57}$ portanto de caráter a priori e o acesso a ela se faz unicamente, dado seu caráter não empírico, através de argumentos reflexivos, ${ }^{58}$ da reflexão do pensamento sobre si mesmo e seus pressupostos irrecusáveis, cuja especificidade

fundamentais: a fundamentação ontológica aristotélico-escolástica e a da filosofia modema da liberdade. Para ele, a filosofia de Leibniz tentou levar a sério ambas as posturas e conciliá-las (Cf.: HEINTEL, E., Grundriss der Dialektik. Ein Beitrag zu ihrer Fundamentalphilosophischen Bedeutung, v. 2, Darmstadt, 1984 , p. 217). A posição do idealismo absoluto aqui apresentada é uma síntese do realismo e do idealismo subjetivo da filosofia transcendental da modemidade.

Que Platão, por primeiro, articulou no ocidente. Cf.: LIMA VAZ, C. H. de, Escritos de Filosofia V. Introdução à Ética Filosófica 2, São Paulo, 2000, p. 98: "Pela primeira vez na história da filosofia a antropologia platônica introduz a distinção que estará presente como uma encruzilhada teórica decisiva nas concepçōes antropológicas posteriores e, particularmente, na Ética: a distinção entre o ser humano como ser natural, integrado na Natureza e submetido às suas leis e ritmos, e o ser humano espiritual, aberto pela inteligência e pela liberdade a uma realidade transnatural, gnosiologicamente transempirica e ontologicamente transcendente... A República... permanece na história da Ética como referência primeira para todas as soluções que serão ulteriormente propostas tendo em vista fundamentar e explicar a estrutura objetiva do agir ético".

57 Esta è uma postura que se pode denominar, no sentido estrito, de "idealismo" na medida em que a validade das normas de nossas açỏes, isto é, seu caráter categórico, se funda no "ser ideal", que não é empírico e vale a priori e sempre e não na particularidade fática, empirica dos costumes e das tradições. Cf.: Lima Vaz, op. cit., p. 97: "[...] a descoberta das Idéias como norma transcendente de toda realidade apresenta-se imediatamente como solução para o problema da objetividade do ethos. Com efeito, as Idéias se manifestam, por sua própria natureza, como normativas dos costumes ou da conduta ou como fundamento real do nómos ou das leis que regem o ethos e a polis. Daqui a expressão modelo ideonômico para caracterizar a solução platônica para o problema da objetividade do mundo ético".

Neste sentido, a filosofia emerge como a reflexão do pensamento sobre si mesmo e sobre seus pressupostos inelimináveis e enquanto tal como uma lógica que se fundamenta a si mesma. Fundamentar é uma relação lógica, o que significa dizer que a lógica não pode ser fundamentada no sentido de que ela pudesse ser fundamentada a partir de fora por algo independente da lógica. Portanto, fundamentação aqui só pode ser pensada como autofundamentação, o que significa dizer que a cadeia de fundamentação não pode ser infinita : para sua fundamentação a lógica só pressupõe a lógica. A fundamentação é portanto um circulo necessário, Esta reflexão não pode em principio ser negada, pois sua negação a pressupöe: como refutar o lógico a não ser com o próprio lógiCo? Dai seu caráter irrefutável e enquanto tal absoluto. Cf.: WANDSCHNEIDER, D., Die Absolutheit des Logischen und das Sein der Natur. Systematische Überlegungen zum absolut-idealistischen Ansatz Hegels, in: Zeitsch. f. phil.Forschung 39(1985)331-351. 
é legitimar os próprios princípios de nosso conhecimento e de nossa ação. Esta reflexão do pensamento sobre si mesmo não pode em princípio ser negada, pois, quem a nega, reflete, utiliza categorias, numa palavra, pressupõe o que nega. A reflexividade do pensamento se revela assim como ponto último e irrecusável de todo conhecimento.

A especificidade destes argumentos é que aqui não se trata de derivação de conhecimento a partir de outro conhecimento, o que seria impossivel quando se trata precisamente de princípios, ${ }^{59}$ mas dizem respeito aos pressupostos necessários do agir. Eles são não somente necessários num ato concreto, pois em toda situação concreta de argumentação muitas coisas são pressupostas que, neste contexto argumentativo, não podem ser negadas sem autocontradição, mas que são inteiramente contingentes e que podem ser negadas por um outro sem autocontradição, por exemplo, que vivo, que estou acordado, etc. Quando se trata, nos argumentos reflexivos, de tematizar os pressupostos necessários, o procedimento não é simplesmente o da contradição entre a dimensão ilocutiva e a dimensão proposicional numa situação de ato de fala contingente e determinada. Trata-se aqui do que V. Hösle ${ }^{60}$ chama de "contradição dialética", que diz respeito a sentenças ou conceitos em si mesmos e isto independentemente do fato de serem proferidos por um ser finito, ou seja, independentemente do ato de uma consciência finita. Assim, por exemplo, a sentença - existe "verdade" - é em si mesma reflexiva, ao contrário da sentença - penso, logo existo - que não fala sobre sentenças e por isto não é reflexiva; aqui apenas o ato é reflexivo.

A reflexão se revela como necessária, uma vez que os princípios, enquanto princípios, não podem ser deduzidos, isto é, demonstrados no sentido de uma dedução, sem que a dedução já os pressuponha e, ao mesmo tempo, não podem ser negados sem autocontradição. Por esta razão, argumentos reflexivos se distinguem tanto da dedução e da quanto da intuição e seu específico é que nos fazem captar o incondicionado, o sem pressuposto ${ }^{61} \mathrm{e}$, por isto, absoluto, ou seja, eles

59 Os argumentos transcendentais são a altemativa tanto a uma teoria intuicionista do conhecimento que se contenta com a simples garantia de suas próprias intuições, quanto ao modelo hipotéticodedutivo de fundamentação, que inevitavelmente conduz a um regresso ao infinito (Cf.: HÖSLE, V., Religion, Theologie, Philosophie, in: Die Philosophie und die Wissenschaften, München, 1999, p. 201-202).

* Cf.: HÖSLE, V., Begründsfragen des objektiven Idealismus, in: Philosophie und Begründung, ed. por Forum für Philosophie Bad Homburg, Frankfurt am Main, 1987, p. 260.

5. Para M. Müller, a tradiçäo denominou esta esfera de "auto-evidente" no sentido de que ela só pode ser compreendida e fundamentada a partir de si mesma e o que constitui a "tarefa própria da filosofia" é o retomo a seu próprio fundamento, que é igualmente fundamento do pensar e do falar, de mim mesmo e daquilo com que tenho a ver. Filosofia é "reflexão transcendental" sobre esta esfera primeira, critério último a partir de onde se pode questionar todo simplesmente dado a respeito de sua verdadeira : salidade e de sua real verdade. Neste sentido a criticidade humana, que é a possibilidade de negar qualquer condicionado, só é possivel porque já sempre estamos no horizonte do incondicionado. Por esta razão, a razão crítica perde sua criticidade, quando não mais tematiza o incondicionado que é sua condição última de possibilidade. Toda verdade tem que ser testada no horizonte da verdade enquanto tal. É a partir daqui que o pensamento é propriamente pensamento e não apenas representação. A verdade enquanto tal "nos desliga" frente a tudo e assim nos faz livres para levantar a questão da validade de tudo. Filosofia é retorno transcendental dos verdadeiros 
nos fazem captar pensamentos objetivos numa razão objetiva, absoluta ${ }^{62}$. A pergunta de Hösle, ${ }^{63}$ neste contexto, é: Por que falar de razão absoluta? Não seria possivel dizer que eles existem independentemente de um pensamento finito, mas que existiriam, de certo modo, como números num mundo ideal sem que se fizesse atribuir a este mundo, pensamento, subjetividade? Trata-se, nos argumentos reflexivos, de estruturas reflexivas às quais não se pode negar uma existência ideal. Como na matemática, a demonstração de sentenças matemáticas verdadeiras ocorre a partir de sentenças matemáticas verdadeiras, então as demonstrações que constituem a demonstração última têm que ser verdades absolutas como as próprias sentenças demonstradas. Assim, a estrutura, associada às sentenças, é uma estrutura que se demonstra a si mesma, que se fundamenta a si mesma; é uma estrutura que fundamenta que ela é uma estrutura que se fundamenta a si mesma, que se constitui enquanto constituindo a si mesma e, enquanto tal, qualquer tentativa de negá-la a pressupõe, ou seja, trata-se de uma estrutura ineliminável, portanto de um ser necessário que se fundamenta a si mesmo reflexivamente. Ora, reflexividade e autofundamentação constituem a essência da subjetividade, a argumentação a essência da razão de tal modo que se deve falar de subjetividade absoluta e razão absoluta. O cerne do procedimento aqui em questão consiste em que ele nos leva a ter de reconhecer não somente uma esfera do lógico, do ser ideal (as determinações universalíssimas de todo ente) irredutível a entidades riaturais, como também a estados da consciência ou a processos intersubjetivos de reconhecimento, mas a realidade da razão absoluta (ser necessário) como seu princípio, que constitui assim o mais íntimo e o centro do pensamento, que subjaz a todo ente e é o pressuposto de todo pensar, portanto, é o fundamento ontológico de tudo.

O ser ideal, o incondicionado e absoluto, é reflexividade e autofundamentação absolutas $^{64}$ e, neste sentido, espírito absoluto, inteligência absoluta, saber que sabe de si mesmo ${ }^{65}$ enquanto reflexão total sobre si mesmo, revelação a si mesmo,

para a verdade (Cf.: MULLER, M., Die Wahrheit der Metaphysik und der Geschichte, in: Erfahrung und Geschichte. Grundzüge einer Philosophie der Freiheit als transzendentale Erfahrung. Freiburg/München, 1971, p. 21-22).

* $\mathrm{O}$ que significa dizer que a fundamentação última, enquanto tematiza, pela mediação de argumentos transcendentais, uma estrutura última que se fundamenta a si mesma, é a "formulação transcendental" daquilo que, a partir de Kant, se chama o "argumento ontológico" da existência de Deus, que é o cerne da filosofia. A respeito de uma compreensão do argumento ontológico, que se aproxima desta posição cf: WEISSMAHR, B. Philosophische Gotteslehre, 2. ed., Stuttgart/Berlin/Köln, 1994, p. 96-100.

63 Cf: Hösle, op. cit., p. 260-261.

64 O que se faz agora è uma explicitação dos momentos da estrutura que se fundamenta a si mesma, portanto, uma explicitação do que já está implicitamente presente no argumento de fundamentação última, o que significa dizer que o argumento ontológico, cerne da metafísica, se revela como a fundamentação última de todo conhecimento e de toda ação.

es Pensamento do pensamento, identidade da inteligência (noûs) e do inteligivel (noetón) como diz Aristóteles, in: Met. XII, 7, 1072 b 21-23. Cf.: Hegel, Enzyklopädie, op. cit., p. 44-46. A metafísica moderna pré-kantiana colocou o argumento ontológico como correlato do principio de razão suficiente, porque aquele principio só tem sentido, se existe uma estrutura última que se fundamenta a si mesma. Cf.: Hösle, Religion, op. cit., p.202. 
auto-iluminação em si mesmo e para si mesmo, ${ }^{66}$ identidade absoluta entre ser e reflexão, Verdade absoluta e fundamental, a pressuposição de toda posição que por esta razão mesma não pode ser deduzida, o chão absoluto a partir de onde podem ser revelados os limites de nosso saber, ${ }^{67}$ fonte e termo de toda verdade, portanto "o primeiro" de todo conhecimento. O Absoluto não se revela enquanto outro frente à razão, mas antes como razão absoluta, identidade plena entre ser $\mathrm{e}$ saber, ${ }^{68}$ principio universal de inteligibilidade de tudo, ${ }^{69}$ que por isto conhece tudo em si mesma : todo o qualquer ente é, enquanto principiado do princípio absoluto, em princípio e na medida mesma em que é, inteligivel, portador de um "logos", de uma logicidade imanente uma vez que a universalidade absoluta do lógico implica que tudo seja a ele submetido e, por esta razão, aberto ao saber. Por outro lado, o espírito finito é a possibilidade de captar o inteligivel de tudo. ${ }^{70} \mathrm{E}$. Coreth ${ }^{71}$ deno-

*6 Exprimindo isto na linguagem de Hegel e Heidegger, J. B. Lotz afirma que o ser contém a reflexão plena e o retorno completo a si mesmo e com isto é o puro ser-para-si (Bei sich, Hegel) ou a iluminidade plena (Lichtung, Heidegger). Cf.: LOTZ, J. B., Aletheia und Orthotes. Versuch einer Deutung im Lichte der Scholastik, in: Sein und Existenz. Kritische Studien in systematischer Absicht, Freiburg/Basel/Wien, 1965, pg. 129.

67. Enquanto ciência do pressuposto de todo saber. Aristóteles denomina a filosofia primeira de "teoria da verdade". Cf: Met. A 993 a 30 e ss. É a partir daqui que se articula o argumento elêntico enquanto refutaçäo do ceticismo. (Cf.: BERTI, E., As razöes de Aristóteles, São Paulo, 1993, p. 93 e ss).

* O que, no ser finito, é apenas identidade relativa, intencional, o que significa que aqui o conhecimento é fazer emergir o outro na interioridade do sujeito, numa identificação formal e não real com ele. Cf.: Coreth E., Metaphysik. Eine methodisch-systematische Grundlegung, 2. ed., Innsbruck/Wien/München, 1964, p. 358. Lima Vaz, Antropologia, op. cit., p. 223: "No homem o espirito é formalmente idêntico ao ser universal, sendo capaz de pensá-lo. Mas é realmente distinto dos seres na sua perfeição existencial : a eles pode livremente inclinar-se, mas não realmente identificarse com eles, o que configura o paradoxo profundo da contemplaçẫo e do amor". OLIVEIRA, M. A de, Filosofia enquanto auto-reflexão da razāo, in: A Filosofia na crise da modernidade, São Paulo, 1989, p. 135: "A realidade se manifesta aqui na interioridade do sujeito, pois o processo do conhecimento, a teoria, aparece essencialmente como um processo de interionizaçāo da realidade.... Esta dimensão é antes de tudo uma dimensão de manifestação, pois é à medida que algo se interioriza que ele manifesta o proprio sentido".

Aristóteles, De Anima, III, 431 b 21 . Cf.: AOUINO, T. de, De Veritate, q. 1 a 1c. MARC, A., La Dialectique de l'Affirmation: essai de Métaphysique réflixive, Paris, 1952, p. Coreth, op. cit., p. 354. Lima Vaz, Antropologia Filosófica II, São Paulo, 1992, p. 104: "Presença que se descobre... transcendental, porque nessa e por essa intuição da presença do ser, a inteligência vê aberto o horizonte de inteligibilidade ilimitada no qual o ser se manifesta, e vê igualmente que é situado neste horizonte que todo e qualquer ente particular pode ser conhecido." Para J. B. Lotz, o ser é verdade ou a razão formal da verdade é o ser; dai porque pelo ente, porque e enquanto a ele compete o ser, é verdadeiro. Cf.: LOTZ, J. B., Ontologia, Barcelona, 1962, p. 118. M. Müller diz que o ser, enquanto verdade, é incaptável, inatingivel no sentido de que ele precede todo captar, representar, conceituar já que nele é que se formam o espaço, o chão de todos os conceitos e podem ser formados representaçōes e objetos. Assim, o ser, enquanto verdade, é um "pré-conceito" que precede todos os conceitos, o "fundamento" (arché) de todo conhecimento verdadeiro. Filosofia é então transcendental enquanto saber "arqueológico", isto é, retorno ao "primeiro" enquanto fonte de inteligibilidade de tudo. Cf.: Müller, op. cit., p. 2021.

\% Precisamente enquanto ser aberto à esfera absoluta, que é fonte de inteligibilidade de tudo. Nesta perspectiva, o tomismo transcendental fala de uma presença atemática de Deus como fundamento de todo e qualquer conhecimento, inclusive do conhecimento explícito do Absoluto na reflexão filosófica e na religião. Cf.: RAHNER, K., Curso fundamental da fé, São Paulo, 1989, p. 71: "Essa experiência e sempre presente - o conhecimento de Deus que sempre temos inclusive quando pensa- 
mina a inteligibilidade dos entes de verdade ôntica ${ }^{72}$ e o saber do espirito finito, enquanto capacidade de captação da inteligibilidade de todas as coisas, de verdade lógica. ${ }^{73}$ Ambas se radicam na verdade ontológica, ${ }^{74}$ enquanto verdade do ser mesmo enquanto tal, ${ }^{75} \mathrm{o}$ "primeiro ineliminável" ${ }^{76}$ sem o qual não existe nem verdade ôntica nem lógica.

mos e lidamos com outras coisas que não Deus - é o fundamento permanente do qual emerge o conhecimento temático de Deus que exercemos na atividade explicitamente religiosa e na reflexão filosófica." Daí a explicação da tensão ineliminável que masrca o ser humano ednquanto ser espiritual finito. Cf.: Lima Vaz, Antropologia, op. cit., p. 217: "Em primeiro lugar, apresenta-se, pois, a tensão interior ao espíito no homem entre a abertura transcendental para o Verdadeiro-em-si e a inclinação transcendental para o Bem-em-si de um lado e, de outro, a limítaçẫo categorial ou eidética do espirito humano que submete a abertura para o Verdadeiro e a inclinação para o Bem à contigência e finitude do próprio sujeito e à mediação do mundo exterior."

Para Coreth, a verdade ôntica consiste em que o ente é adequado ao espínto e enquanto tal pode ser captado pelo saber. $O$ ente é a possibilidade de ser captado e posto pelo espírito; a verdade lógica, por sua vez, consiste na adequação do saber do espirito ao ente, enquanto ele, ao saber, pöe o ente, como ele é em si mesmo. O espírito finito é a capacidade de pôr o ente no saber (Cf.: Coreth, op. cit., p. 351). A verdade ôntica é a logicidade imanente de cada realidade, sua essência. É somente a partir do conhecimento das essências que é possivel pensar numa hierarquia de bens, o que é indispensável para nossas escolhas (Cf.: Hösle, Moral und Politik, op. cit., p. 154 e ss).

Para Tomás de Aquino (De Veritate, q. 1 a 9) a filosofia encontra seu fundamento na abertura do espirito humano à verdade originária que ele atinge através da reflexão sobre si mesmo. Cf.: Putallaz F.X, Le sens de la réflexion chez Saint Thomas d'Aquin, Paris, 1991, p. 189-201. B. Weissmahr afirma que $o$ incondicionado da verdade, que se mostra no caráter incondicional da contraposição entre proposições verdadeiras e falsas, não significa que nossas proposiçōes, expressamente formuladas, não sejam condicionadas sob muitos aspectos. Nossas proposições, expressas em sentenças, estão sempre num contexto e só neste contexto possuem uma significação precisa. Conseqüentemente, a verdade de cada sentença é condicionada de diferentes formas. Porém exatamente o fato de que nós conhecemos isto, é a prova mais clara da presença do Absoluto em nosso conhecimento. Pois, o conhecimento do relativo enquanto relativo pressupōe necessariamente o conhecimento atemático do Absoluto (Cf.: Weissmahr, Philosophische Gotteslehre, op. cit., p. 31-32).

"7 A revolução copemicana de Kant vai consistir em deslocar o eixo da reflexäo filosófica do "ontológico absoluto" para a esfera do epístemológico. Cf.: Lima Vaz, op. cit., p. 104: "[...] arrastado no movimento da crítica da Razão que conduz do ser ao sujeito, o lugar inteligivel do 'transcendental' desloca-se do solo ontológico para o solo gnosiológico", onde "a experiência noética da Verdade ficará circunscrita às condiçōes da experiência organizadora dos fenômenos, ou seja, à finitude da situação do sujeito no mundo". A conseqüência para a razão prática é radical. Cf.: Lima Vaz, São Paulo, 2000, p. 101: "[...] o modelo ideonômico da tradiçäo platônico-aristotélica é reinterpretado como modelo autonômico (Kant), segundo o qual a objetividade do agir ético tem seu fundamento na atividade autolegisladora da liberdade".

76 Para Espinosa, a substância absoluta é destituída de sabedoria e vontade (Ética Primeira Parte, n. XVII, Escólio), pois ambas implicam oposição, o que é incompativel com a substância absoluta. Pode-se dizer, na linguagem de Coreth, que aqui se pensa no horizonte da verdade ôntica e da verdade lógica, que são verdades derivadas e não propriamente no nível da verdade ontológica, que é a esfera originária a partir de onde se pode entender a verdade ôntica e a verdade lógica. Uma dificuldade análoga tem Kutschera para falar da bondade de Deus (Cf: Kutschera F. von, Vernunft und Glaube, Berlin/New York, 1991, p. 51-54).

76 A expressão é de M.Müller. Cf.: Müller, op. cit., p. 20. O tomismo transcendental afirma, a partir daqui, que o Absoluto pertence, a partir do fundo, ao conteúdo da nossa consciência. Isto significa: a Realidade Absoluta está sempre presente em nosso conhecimento como conhecida, porém não na forma de uma essência expressamente conhecida de um objeto, mas antes como o fundamento da objetividade de todo nosso conhecimento expresso. Só temos acesso expresso a esta Realidade através da reflexão transcendental sobre as condições necessárias de nosso conhecímento de objetos. Numa palavra, o Absoluto pertence ao conteúdo de nossa consciência, embora nunca enquan- 
O ser ideal, por sua vez, enquanto razão absoluta, sabe de si, intui absolutamente a si mesmo (nóesis noéseos) e se afirma a si mesmo, ${ }^{77}$ põe-se a si mesmo incondicionalmente $e$, portanto, é fundamento de si mesmo, tem em si mesmo sua razão de ser (causa sui) ${ }^{78}$ e é fim em si mesmo, revelando-se, então, como autoposição, autodeterminação e auto-afirmação originárias de si como ser absoluto. Ele mesmo, enquanto razão absoluta que se fundamenta a si mesma, é razão que fundamenta sua auto-afirmação, sua amabilidade originária, ou seja, seu valor intrínseco absoluto, ${ }^{79}$ que não tem outro fundamento senão a si mesmo, sua bondade absoluta e fontal. Enquanto princípio, a esfera incondicionada é então a fonte de toda e qualquer amabilidade dos principiados, ou seja, o fundamento absoluto de todo e qualquer bem ${ }^{80}$ e enquanto princípio imanentemente presente em qualquer bem e, igualmente, transcendente a tudo e, neste sentido, fundamento absoluto de nosso agir, o que significa dizer que nossa ação se situa no horizonte do Absoluto, isto é, o ser humano é, em princípio, orientado para a validade incondicional, ${ }^{81}$ portanto, para um sentido último e, neste sentido, tanto mais é ele mesmo quanto mais tem consciência de não ser simplesmente o criador de sua própria

to um objeto claramente captado. Por esta razão, as tentativas de traduzir este conhecimento atemático, num conhecimento temático, objetivo, através da reflexão filosófica, são sempre muito precárias (Cf.: Weissmahr, Philosophische Gotteslehre, op. cit., p. 26-27-36).

n Cf.: Lima Vaz, Antropologia, op. cit., p. 219: "A forma do existir do espírito é, portanto, a própria correlaçăo dialética entre razão e liberdade. A razão é acolhimento do ser, a liberdade é consentimento do ser".

7. Met. I, 982 b 26. Aquino, Summa C. Gentiles, II c. 48. E assim, liberdade absoluta (Cf.: Plotino, En., VI, 8). Para Hegel, a essência do espirito é formalmente a liberdade, a negatividade absoluta do conceito enquanto identidade consigo. A definição suprema do Absoluto é que Ele é Espírito (Cf.: Hegel, Enzyklopädie der philosophischen Wissenschaften 1830, ed. por Nicolin F./Pöggeler O, Hamburg 1959, §§382-384).

7 Cf.: Platão, República, sobretudo liv. VI. Aristóteles, Met. I, 7; Et. Nic. I, 6; VIII, 2-5.Para Tomás de Aquino, o bem é o perfeito. Cf.: Cont. gent. I, 37: "Naturaliter enim uniuscujusque bonum est actio et perfectio". S.th. I, 5 3: "Perfectum habet rationem appetibilis et finis". J. de Finance comenta a postura de Tomás afirmando que perfeito é o que realiza sua essência, é o que é plenamente o que è e enquanto tal é amável . Neste sentido, o sujeito deseja sua própria perfeição, ou antes deseja a si mesmo como perfeito, como realizaçăo plena de sua essência e isto em virtude de um amor mais radical de si, que é adesão a si mesmo em seu ser. 0 desejo surge da ausência do bem e portanto pressupõe logicamente um momento de adesão pura, de simples complacência. O sujeito se compraz antecipativamente em seu ser acabado ou seu ideal. O desejo se explica por ser o ideal justamente ideal, isto é não-real. Conseqüentemente temos que dizer que a razão absoluta é a adesão plena a seu ser absoluto, amor radical de si enquanto realização plena, portanto enquanto perfeição absoluta (Cf.: DE FINANCE, J., Essai sur l'agir humain, Rome, 1962, p. 88-90).

so Em De Ver. 24, 7. Tomás chama este fundamento absoluto de: "ipsum universale bonorum principium". Analogicamente ao momento da verdade, se explicita aqui o momento "bondade" implícito, portanto, já no argumento de fundamentação última, o que significa dizer que o argumento ontológico é o fundamento do caráter categórico da lei moral, o que marca a diferença com o tipo de fundamentação transcendental articulada pela pragmática transcendental.

O que torna possivel ao ser humano perguntar pela verdade de seus conhecimentos e pela correção de suas açöes e assim distanciar-se de toda facticidade. Isto o distancia, em sua ação, da submissảo necessária às convenções șociais ou ao determinismo da natureza. Cf.: OLTVEIRA, M. A. de, A liberdade enquanto sintese de opostos: transcendência, engajamento e institucionalidade, in: Veritas, v. 44, n. 4, 1999, p. 1024. Cf.: Lima Vaz, Antropologia Filosófica I, São Paulo, 1991, p. 211: “O espírito finito é logos ou ordem necessária de inteligibilidade e bondade enquanto participa da ordem arquetipal da Inteligência infinita e da ordem e medida da lei eterna da Liberdade infinita". 
liberdade, portanto consciência de sua finitude radical. Nesta perspectiva, todo bem principiado é, por um lado, relativo e condicionado, ${ }^{82}$ por outro, porém, afirmado e buscado no horizonte do bem absoluto, ${ }^{83}$ isto é, em identidade e nãoidentidade com o Bem absoluto.

Em analogia com a problemática da verdade, E. Coreth ${ }^{84}$ distingue aqui entre a bondade ôntica (o bonum onticum ou naturale da tradição), que é a bondade de que é portador cada ente na medida em que é principiado da bondade absoluta e enquanto tal nunca plenamente bom, ${ }^{85}$ trata-se da amabilidade do ente na medida mesma e no grau em que é ente. ${ }^{86}$ Todo ente, enquanto principiado é inteligível (aberto ao saber, à inteligência) e estimável ${ }^{87}$ (aberto à afirmação do querer, à

Cf.: OLIVEIRA, M. A. de, A Liberdade enquanto sintese de opostos: transcendência, engajamento e institucionalidade, in: Veritas, v. 44, n. 4, 1999, p. 1028: "Precisamente porque o ser humano é presença do incondicionado, ele é capaz de transcender qualquer condicionado, qualquer valor particular de ser e, assim, está sempre para além de si mesmo. É a presença do incondicionado que lhe dá o poder de pôr em questäo qualquer objeto, inclusive a si mesmo enquanto objeto de si mesmo". Por outro lado, é pela mediação destes bens condicionados que o ser humano vai efetivando seu ser. Cf.: Lima Vaz, Escritos de Filosofia V, op. cit., p. 109: "Nessa sua presença no sujeito o bem irá torná-lo participante de sua bondade ontológica ou da sua perfeição como ser. A face do bem pela qual ele confere ao sujeito a sua perfeição e, como tal, é por ele desejado e apreciado (Et. Nic., I, 1, 1094 a 2) é designada modemamente com o termo valor". Página 33: "O fim da práxis é a auto-realização do sujeito pela consecução do bem que the é conveniente [...]. A obra humana por excelência [...] é, sem dúvida, a realização plena da própria vida, orientada pela Razão prătica". Cf.: Aquino, De Ver., 22, 2: "[...] sicut Deus, propter hoc quod est primus efficiens, agit in omni agente, ita propter hoc quod est ultimus finis, appetitur in omni fine". É nesta perspectiva que B. Welte afirma que no mais profundo de nosso ser-no-mundo encontramos, de forma oculta, o vestigio do Bem Absoluto, que muitas vezes denominamos sentido ou felicidade, enquanto o vestígio de um poder infinito e incondicional. Por esta razão, O Incondicionado e Infinito vive na raiz mais íntima de nosso existir no mundo e esta abertura à esfera do Incondicionado é o fundamento de nossa essência como espirito finito no mundo. Daí porque ser homem significa, de um certo modo (ele usa a palavra latina quodammodo), unidade com o Infinito e o Absoluto (Cf.: WELTE, B., Das Gute und die Einheit der Unterschiedenen. Eine tomistische Betrachtung, in: ENGELHARDT, P. (org.), Sein und Ethos. Untersuchungen zur Grundlegung der Ethik, Mainz, 1963, p. 137-138). Cf.: Coreth, op. cit., p. 368 e ss.

Cf.: Lima Vaz, Escritos de Filosofia V, op. cit., p. 106: "As categorias que exprimem, na concepção clássica, o horizonte objetivo ao qual se refere 0 agir ético pensado no momento lógico-dialético da universalidade são as categorias de Fim e de Bem entre as quais vigora uma inter-relação análoga à que, na estrutura subjetiva, se estabelece entre razão e liberdade. O fim conhecido pela razão é o bem do sujeito, e o bem ao qual a vontade deve consentir é fim tal como a razão o conhece".

Para J. B. Lotz, Tomás considera o bem como princípio último que, enquanto tal, não pode ser definido, uma vez que pressuposto por qualquer definição, mas pode ser descrito como o que convém a algo ("id quod alicui conveniens est"). Tomás de Aquino, no De Veritate I, I, diz que o bem. enquanto determinação transcendental, pertence à esfera da conveniência de um ente a outro convenientia unius entis ad aliud - mais especificamente ainda - convenientia ad appetitum. Conveniente é o que constitui a perfeição de algo. Ora, o que é sumamente conveniente é o próprio ser do qual participam todas as conveniências. Portanto, todo ente é bom na medida em que corresponde a sua essência que é sua forma própria de ser. Cf.: Lotz, Ontologia, op. cit., p. 134. A respeito do sentido de "bom" no contexto da filosofia analítica cf: RICKEN, F., Allgemeine Ethik, 2. ed., Stuttgart/Berlin/Köln, 1989, p. 54-66. TUGENDHAT, E., Vorlesungen über Ethik, 2. ed., Frankfurt am Main, 1994, p. 49-64. HARE, R. M., A linguagem da Moral, São Paulo, 1996, p. 85-158. No contexto da problemática da "vida boa": WOLF, J.-C./ SCHABER, P., Analytische Moralphilosophie, Freiburg/München, 1998, p. 173-187.

* Para Tomás de Aquino 0 ato espiritual é a unidade sintética de seus dois momentos : inteligência e vontade (Cf.: St. Th., Ia, q. 19 a 1 c; De Veritate, q. 23 a 1). 
vontade $)^{88}$ e, por outro lado, a bondade presente na ação humana que afirma a bondade dos entes em si mesma como valor intrínseco a eles, que ele denomina de bondade realizada (o bonum exercitum da tradição) (poderiamos chamar de bondade ética). A bondade ôntica se transforma em bondade realizada na medida em que é posta, ratificada pela vontade humana enquanto bondade em si. ${ }^{89} \mathrm{Am}$ bas as formas de bondade se radicam na bondade ontológica, auto-afirmação, auto-estima do Absoluto enquanto absoluto, ${ }^{90}$ autodeterminação incondicional e enquanto tal liberdade absoluta. ${ }^{91} \mathrm{O}$ ser ideal se explicita então como Verdade e Bondade originárias e o ser humano é precisamente ser racional enquanto capacidade de retorno transcendental à medida última de toda verdade (Verdade Primeira) e de toda bondade (Fim Último).

Pode-se dizer que se fala aqui adequadamente de "fim último" ${ }^{\text {"92 }}$ na medida em que ele não é querido diretamente por nenhum ato de vontade humana e não pode ser realizado imediatamente em nenhuma ação: o Último é aquilo por causa de que se faz tudo o que se faz. Por esta razão, já estamos sempre nele, porque é a esfera de possibilitação de todo nosso agir, e, por outro lado, estamos sempre fora dele, enquanto radicalmente transcendente. $O$ que é Primeiro, enquanto verdade, na ordem do conhecer, é o último, enquanto bondade, na ordem do agir, portanto é Fim Último, ${ }^{93}$ sempre imanente como o buscado, em última instância, em todas as nossas ações, mas igualmente radicalmente transcendente a todas elas. Filosofia é então, enquanto reflexão transcendental, tematização da razão

Æ É neste sentido que Tomás de Aquino diz que todo ente, na medida em que é ente e portanto é principiado do Absoluto, possui perfeição, é perfeito em seu grau especifico de ser. Cf.: S. Th., q. 5 a 1: "Manifestum est autem quod unumquodque est appetibile secundum quod est perfectum: nam omnia appetunt suam perfectionem. Intantum est autem perfectum unumquodque, inquantum est actu: unde manifestum est quod intantum est aliquid bonum, inquantum est ens: esse est enim actualitas omnis rei [...]".

* B. Welte, interpretando o pensamento de Tomás de Aquino no horizonte da filosofia heideggeriana, diz que o ente, pensado isoladamente, enquanto coisa em si fora do horizonte de uma tendência, não poderia ser bom. Por outro lado, o ser humano sem a consideração de um possivel para onde da alma apetitiva também não poderia ser bom. Só no encontro dos dois, na "conveniência" entre os dois, no ser uno enquanto ser-no-mundo há e se efetiva o bem. Cf.: WELTE, B., Das Gute als Einheit des Unterschiedenen. Eine tomistische Betrachtung, in: Engelhardt, op. cit., p. 130.

Que é, na expressão de B. Welte, o pressuposto para que possamos captar a racionalidade imanente às coisas e afirmar sua bondade objetiva. Cf.: Welte, op. cit., p. 137.

91 Para J. B. Lotz, Deus é autodisposição absoluta de Si mesmo, o que implica necessidade e liberdade em identidade extrema; na liberdade se cumpre a necessidade e na necessidade se cumpre a liberdade; suprema necessidade é suprema liberdade. Sua atividade necessária provém única e exclusivamente de seu ser absoluto e enquanto tal é liberdade absoluta. Deus é o que diz um sim infinito a Si mesmo, Ele é o infinitamente decidido por Si mesmo. Em seu agora etemo, realiza Ele sua autodisposição absoluta e com isto a liberdade absoluta (Cf.: LOTZ, J. B., Person und Freiheit. Eine philosophische Untersuchung mit theologischen Ausblicken, Freiburg/Basel/Wien, 1979, p. 141).

22 Cf: Müller, op. cit., p. 25.

93 Para M. Müller, a presença do Primeiro é passado absoluto, a ausência do Úitimo é futuro absoluto (Cf.: Müller, op. cit., p. 25). 
absoluta como Primeiro (Verdade) e Último (Bondade) ${ }^{94}$ e neste sentido "metafisica" e enquanto tal "fundamentação última do conhecimento e da ação (ética). ${ }^{96}$

Com isto, o que foi feito, foi simplesmente enfrentar a pergunta de onde partimos que brota em cada situação histórica em que seres humanos estão inseridos: que devemos fazer? Tratava-se, portanto, de explicitar o espaço de fundamentação ${ }^{96}$ das normas que nos regem em nossa vida histórica e sobretudo seu caráter categórico. Ora, a verdade fundamental da tese da falácia naturalista de Hume, que se explicitou através da reflexão transcendental, está precisamente em mostrar que o dever ser não se fundamenta no ser empírico (histórico), mas no ser ideal (metafísico), na esfera absoluta, Verdade e Bondade absolutas, que, portanto, não é empírico, não pertence ao mundo dos fenômenos, vale a priori e sempre. ${ }^{97} \mathrm{O}$ ato subjetivo, porém, com que alguém capta a lei moral intemporal e a relaciona a suas intenções pertence à ordem causal do mundo empirico. Por ser o ser humano um espírito finito, a consideração de suas intenções, que são intenções de um ser inserido num mundo histórico intersubjetivamente construído e no contexto da natureza, portanto na esfera da contingência, da particularidade e da mudança, é o ponto obrigatório de partida da reflexão ética. Estas intenções precisam da avaliação crítica a partir do critério universal do ser ideal. Numa palavra, o universalismo é uma dimensão fundamental da ação ética, porque significa a referência explícita da vida fática à esfera do fundamento, ${ }^{98}$ mas só existe ética na medida

4. Tomás de Aquino (Summa. Theol. Ia, q.82, a 4 ad 1m) fala do entrelaçamento mútuo entre verdade e bondade, entre inteligência e vontade. Cf.: Lima Vaz, Antropologia, op. cit., p. 213: "Essas duas intencionalidades do espírito (ou do homem como espírito) enquanto inteligente e livre se cruzam na unidade do movimento espiritual: pois a verdade é o bem da inteligência e a bem é a verdade da liberdade. É esse o quiasmo do espírito finito que, no Espirito infinito, é identidade absoluta da verdade e do bem". Dai a conseqüência: Página 232, nota 63: "No espirito teorético o objeto recebe a forma da universalidade e da necessidade (Razão): no espirito prático, o objeto recebe a forma da ordenação para o fim ou do fim em si (Liberdade). Na sintese dos dois, a liberdade é racional e a razão é livre(quiasmo do espírito)".

96 Para M.Müller, filosofia é "arqueologia e escatologia transcendentais" e enquanto tal "teologia" (Cf: Müller, op. cit., p. 26).

* Toda a argumentação teve como pano de fundo um confronto, pelo menos, com outros três tipos de fundamentação transcendental hoje conhecidos. 1) A Pragmática Transcendental. Cf.: APEL, K.O., Das Apriori der Kommunikationsgemeinschaft und die Grundlagen der Ethik, in: Transformation der Philosophie, v. 2, Frankfurt am Main, 1976, p. 358-435; Diskurs und Verantwortung. Das Problem des Übergangs zur postkonventionalen Moral, Frankfurt am Main, 1998; Éthique de la discussion, Paris, 1994. 2) Teoria da ação comunicativa. Cf.: HABERMAS, J., Moralbewusstsein und kommunikatives Handeln, Frankfurt am Main, 1983; Richtigkeit versus Wahrheit. Zum Sinn der Sollgeltung moralischer Urteile und Normen, in: Wahrheit und Rechtfertigung. Philosophische Aufsätze, Frankfurt am Main, 1999, pg.271-318. 3) O Contratualismo transcendental. Cf.: Höffe, Demokratie im Zeitalter der Globalisierung, München, 1999.

\$7. Pode-se dizer que o que caracteriza a forma dialética de pensar, que Platão nos legou, consiste fundamentalmente no esforço de superar a dicotomia radical e pensar uma síntese entre historicidade e idealidade. Assim, nosso desafio hoje é rescrever a República a partir do contexto formação de um mundo globalizado. A pergunta que se impõe a partir de nossa historicidade é: como definir o horizonte objetivo de uma ética global?

9 Para Lima Vaz, a formulação dialética desta problemática implica uma dupla negação. Cf.: Lima Vaz, Escritos de Filosofia V. Introdução à Ética Filosófica 2, São Paulo, 2000, p. 104: “Com efeito a relação entre o agir, individual e comunitário, e seu objeto se mostra como uma relação dialética no sentido de que seus termos se referem um ao outro por meio de uma dupla Para Lima Vaz, a for- 
em que o universal se efetiva na particularidade das situações históricas, que constituem o horizonte objetivo imediato da práxis humana, o que manifesta o circulo ineliminável da ação ética: ela parte da particularidade das situações históricas (historicidade), se eleva à esfera da universalidade ideal (metafísica) ${ }^{99}$ e retorna à particularidade histórica (historicidade) na medida em que a ação ética é o esforço de traduzir o universal nas situações. ${ }^{100}$

Daqui se segue o postulado da universabilidade: algo é prescrito ou proibido a um ser racional, quando o é igualmente a todos os seres racionais, que contêm em si mesmo uma primeira exigência ética básica: a exigência de relações simétricas entre todos os seres racionais. O universalismo é necessário, mas insuficiente: ${ }^{101}$ diz que, se existe uma norma para alguém, esta tem que ser universal, mas não diz que há normas e quais. Ora, o espírito finito, enquanto razão e liberdade, capta a racionalidade presente em tudo e conseqüentemente a hierarquia dos seres, que em conseqüência do entrelaçamento da verdade e do bem, implica uma multiplicidade hierárquica de bens e valores ${ }^{102}$ sem o que é impossivel resolver os conflitos na vida humana. No horizonte desta forma de reflexão ética, o imperativo categórico kantiano, a expressão mais articulada da ética na modernidade, recebe uma nova formulação: "realize tantos valores quanto possivel e no caso de conflito, prefira o valor maior ao menor", ${ }^{103}$ o que significa dizer que toda ética implica uma dialética entre o universal (ser ideal, o princípio) e o particular (os bens e valores,

mulação dialética desta problemática implica uma dupla negação. Cf.: Lima Vaz, Escritos de Filosofia V. Introdução à Ética Filosófica 2, São Paulo, 2000, p. 104: "Com efeito a relação entre o agir, individual e comunitário, e seu objeto se mostra como uma relação dialética no sentido de que seus termos se referem um ao outro por meio de uma dupla negaçăo: o ato nega o objeto em seu teor simplesmente empírico ou indiferente pois com ele se relaciona justamente sob a razão do bem; e o objeto nega a autonomia do ato - ou do sujeito - na gênese total do bem, pois só ele confere ao bem um conteúdo real".

9 A reflexão transcendental que fizemos nos mostrou o sujeito humano fundamentalmente aberto à estrutura que se fundamenta a si mesma e fundamenta tudo mais enquanto princípio de tudo como seus principiados, à Razâo Absoluta enquanto unidade de Verdade e Bondade, o que significa dizer que o ser humano é ordenado à Verdade e ao Bem. Cf.: Lima Vaz, Escritos de Filosofia V, op. cit., p. 35: "[...] a identidade perseguida pela Razão prática entre o seu ato próprio que é a práxis e seu objeto último, a Verdade e o Bem, permanece no plano intencional, ou seja, como identidade na diferença. Nesse caso a identidade da Razão prática e do universal se manifesta como simples forma, ao passo que a diferença provém do conteúdo que é sempre particular".

Daí a importância fundamental do saberempírico na esfera da ética. Cf.: Oliveira $M$. A. de, Ética $e$ Economia, São Paulo, 1955, p. 74 e ss. Hösle, Moral e Politik, op. cit., 175 e ss.

101 Cf: Hösle, Moral und Politik, op. cit., 154 e ss.

ke Cf.: Lima Vaz, Escritos de Filosofia V, op. cit., p. 109: "Nessa sua presença no sujeito o bem irá torná-lo participante de sua bondade ontológica ou da sua perfeiçăo como ser. A face do bem pela qual ele confere ao sujeito a sua perfeição e, como tal, é desejado e apreciado (Et. Nic. I, 1, 1094 a 2) é designada modernamente como o termo valor". Página 110: "Ao tornar-se medida real da liberdade, o bem é avaliado pelo sujeito ético como sendo a forma efetiva da sua realização como ser livre e assume a forma consiste nisto que bens são objetos, eventualmente, ações e eventos, aos quais são ligados valores como qualidades. Cf.: Hösle, Moral und Politik, op. cit., p. 156.

109 Na formulação de V. Hösle. Cf.: HÖSLE, V., Grösse und Grenzen von Kants praktischer Philosophie, in: Praktische Philosophie in der modemen Welt, München, 1992, p. 35. 
os principiados). A norma moral emerge como a síntese entre o universal da esfera absoluta e a particularidade das situações históricas. ${ }^{104}$

Entre estas normas que efetivam a síntese entre o universal e o particular há algumas que podem ou devem, por razões morais, ser impostas através de meios de coerção. É isto o que tradição chamou de direito "natural" ${ }^{105}$ precisamente para exprimir o caráter de transcendência em relação ao direito estabelecido historicamente nas comunidades humanas (o direito positivo) e sua função de critério de julgamento ético do direito positivo. Ele é critério de julgamento precisamente por exprimir a dignidade incondicional do ser humano enquanto espírito finito, ${ }^{106}$ ou seja, enquanto ser racional e livre, ordenado essencialmente para a verdade e para o bem e, por esta razão, portador de um sentido absoluto, que o faz fim em si mesmo.

Neste sentido, o direito positivo só se legitima na medida em que constitui o esforço, sempre de novo a ser feito, de traduzir, em circunstâncias históricas diferenciadas, o direito natural, o que significa dizer que ele só pode ser entendido e fundamentado enquanto objetivação social do direito natural. ${ }^{107}$ Ele é assim uma mediação, cujo sentido específico é abrir o espaço para a efetivação do espírito finito, enquanto ser racional e livre, a nível da convivência dos seres humanos entre si e com a natureza. O direito é então a regra da configuração histórica do conviver e enquanto uma instituição fundamental da liberdade, a "razão reta" ${ }^{108}$ das comunidades humanas, cujo exercício efetivo constitui a justiça, ${ }^{109}$ ou seja, o conjunto de princípios que estabelecem a ordenação da vida social. Desta forma, o direito natural não substitui o direito positivo, mas antes é uma exigência fundamental do direito natural que ele se traduza na forma de direito positivo, ${ }^{110}$ de

104 Cf.: Lima Vaz, Escritos de Filosofia V, op. cit., p. 116: "A norma... é a forma objetiva segundo a qual a universalidade do Bem e do Valor é determinada na particularidade das situaçőes". Cf.: Hösle, Moral und Politik, op. cit., p. 776 e ss.

${ }^{106}$ Cf.: OLIVEIRA, M. A de., Direito e Sociedade, in: PINHEIRO, J. E./JÚNIOR, J .G. de SOUSA/DINIS, M./SAMPAIO, P. de Arruda (orgs.), Ética, Justiça e Direito, Petrópolis, 1996, p. 85.

10\% Cf.: Lima Vaz, Escritos de Filosofia V, op. cit., p. 116: "Com efeito, se a norma se constitui como referência objetiva na estrutura interna do agir ético, derivando imediatamente a sua obrigatoriedade do Bem conhecido e amado, a lei pode ser interpretada como a norma fixada ou codificada na sua objetividade ao se impor como regra exterior do agir e ao fundamentar sua obrigatoriedade no Bem mediatizado socialmente e por uma autoridade legisladora e reconhecida como tal". Página 119: "No caso da lei o bem se comunica ao sujeito pela mediação de uma instância exterior que é o poder socialmente legitimado e a essa comunicação do bem corresponde a obrigação civil [...]. O Direito é correlativo à lei e, como tal, está presente no horizonte objetivo do agir ético".

Na expressão é de Lima Vaz. Cf.: Lima Vaz, Escritos de Filosofia V, p. 121. Para Höffe se pode comparar o direito com a gramática. Assim como a gramática numa língua estabelece o quadro do uso correto da língua, assim as regras de coerção estabelecem a ordem e a estrutura da convivência entre as pessoas. Neste sentido se pode dizer que o direito é a gramática da convivência humana, uma gramática social universalmente válida, que estabelece a forma jurídica do conviver. Ele põe assim as condições de possibilidade da vida em comum Cf.: Höffe, op. cit., p. 59.

108 KERBER, W., Sozialethik, Stuttgart/Berlin/Köln, 1998, p. 75.

110 Cf.: Oliveira, op. cit., p. 83-84: "[...] o direito possui duas raízes. A primeira é a liberdade transcendental e os principios que dela decorrem e a segunda a própria história, o mundo concreto da comunidade humana em questão. Isto implica dizer que os mesmos princípios conduzem a diferentes 
segurança jurídica, que encontre uma determinação, compatível com o direito natural, que possa evitar conflitos. Neste sentido só um Estado que é capaz de vincular justiça e segurança jurídica se pode chamar com razão "estado de direito". "' Por esta razão, tanto o Estado como o direito positivo podem ser falsos: eles podem por exemplo, "fixar uma configuração do direito que não mais corresponde à consciência que a comunidade em questão já atingiu: aqui se revela uma contraposição entre a consciência e a configuração existente. Um exemplo disto é o caso do direito de propriedade, quando sua configuração específica não reconhece a hipoteca social, algo que já faz parte da consciência das sociedades ocidentais. Os direitos da liberdade são também direitos históricos e em seu nome é que se deve protestar contra formulações do direito positivo que entram em contradição com eles. Neste caso ocorre a perversão do direito positivo: ao invés de mediação de efetivação da liberdade, ele se torna instrumento de repressão." ${ }^{112}$

Tarefa fundamental para a ética e a filosofia do direito contemporâneas ${ }^{113}$ é repor a questão dos direitos fundamentais ${ }^{114} \mathrm{e}$ o problema da busca da configuração jurídica que seja capaz de se fazer mediação de liberdade num mundo globalizado, ou seja, explicitar a orientação básica ${ }^{115}$ que abra um espaço de futuro para os

configuraçōes do direito através das quais a liberdade, que é, essencialmente, histórica se efetiva de acordo precisamente com as condições epocais. Trata-se, assim de encontrar em cada situação histórica específica a configuração do direito que tome a liberdade efetiva".

it Cf: Hösle, Moral und Politik, op. cit., p. 779. É neste sentido que Höffe afirma existir um principio de justiça que precede qualquer outro, que é a exigência universal de direito: enquanto conjunto de regras universais rigorosamente válidas o direito emerge como contraposto ao arbitrio pessoal e à violência pessoal e por esta razão deve reinar, em todos os lugares, entre os seres humanos. $O$ direito é então portador de uma força emancipatória uma vez que nos liberta do arbitrio e da violência (Cf.: Höffe, op. cit., p. 61).

112. Cf.: Oliveira, op. cit., p. 8485.

113 Tentativas de efetivação desta tarefa são entre outras: APEL, K.-O., Die Transformation der Philosophie, dois v., Frankfurt am Main, 1973 (tradução brasileira na Editora Loyola, São Paulo, 2000); Diskurs und Verantwortung. Das Problem des Übergangs zur poskonventionellen Moral, Frankfurt am Main, 1988; Éthique de la discussion, Paris, 1994; Estudos de Moral Moderna, Petrópolis, 1994. Henrich D., Ethik zum nuklearen Frieden, Frankfurt am Main, 1990 (o livro foi escrito antes do fim da guerra fria, mas contèm elementos ainda hoje fundamentais). JONAS, H., Das Prinzip Verantwortung. Versuch einer Ethik für die technologische Zivilisation, Frankfurt am Main, 1989. Morin E./Kem B., Terre-Patrie, Paris, 1993. HUBER, W./REUTER, H. R., Friedensethik, Stuttgart/Berlin/Köln, 1990. Hösle, op. cit., Höffe, op. cit.

114 A respeito da discussäo atual sobre os direitos no mundo de língua inglesa cf:: GOYARD-FABRE, S., La philosophie morale et politique: entre le contractualisme et l'utilitarisme, in: MEYER, M. (org.), La philosohie anglo-saxone, Paris, 1994, p. 141 e ss. De modo especial sobre a questäo ecológica: TAYLOR, P. A., Respect of Nature. A Theory of Environmental Ethics, Princeton, 1986. REGAN, T., All that Dwell Therein. Essays on Animal Rights and Environmental Ethics, London, 1982. SINGER, P., All Animals are equal, in: Applied Ethics, Oxford, 1986. No mundo alemāo sobretudo: Hösle, op. cit., p. 792 e ss. Höffe, op. cit., p. 62-94.

115

Ou seja padrōes éticos de validade universal (contra os defensores de éticas regionais como $\mathrm{R}$. Bubner, M. Foucault, R. Rorty e A Macintyre). Esta é a questão central de nossa epocalidade histórica enquanto mundo globalizado. Cf.: WALZER, M., Spheres of justice. A Defense of Pluralism and Equality, New York, 1983; Thick and Thin. Moral Argument at Home and Abroad, Notre Dame/Ind., 1994. KÜNG, H., Uma ética global para a Politica e a Economia Mundiais, Petrópolis, 1999, p. 170: "Mas, por mais diversas que sejam as diferenças nacionais, culturais e religiosas, em toda parte trata-se de pessoas humanas e, estas pessoas humanas, hoje em dia, sentem-se, através dos modernos sistemas de comunicação, sobretudo do rádio e da televisão, cada vez mais como uma comu- 
seres humanos, uma vez que a globalização constitui um desafio fundamental para a humanidade contemporânea por implicar uma nova distribuição econômica e política do poder a nível mundial, o que cria possibilidades inteiramente novas, e, ao mesmo tempo, problemas novos com conseqüências desastrosas para milhões de vidas humanas. Sem dúvida se pode falar de grande eficiência na integração do mercado mundial, mas a questão ética fundamental é que tudo indica que não é nada eficiente a distribuição desta riqueza gerada pela economia mundial, o que leva analistas de nosso tempo a se perguntar se o número de perdedores deste processo não supera de longe o número dos ganhadores. ${ }^{116}$

Isto implica, em primeiro lugar, a recuperação da dimensão ética da atividade econômica, ou seja, o reconhecimento do sentido fundamental da atividade econômica na vida humana, a saber, de uma atividade a serviço da reprodução material do espírito finito, ser racional e livre e que por isto precisa ser configurada de tal modo que ela se subordine aos objetivos éticos da justiça social e ecológica. Numa palavra, importa hoje refletir sobre os princípios de uma injustiça global, que explicitaria as exigências elementares de uma ordem global a serviço do ser livre. Problemas como condições de trabalho, a propriedade, o direito à subsistência, aos serviços sociais básicos, a questão das gerações futuras, as chances de formação e reciclagem, o tipo de desenvolvimento, a questão ecológica, tudo isto tem que ser repensado na perspectiva da construção de uma economia global comprometida politicamente com objetivos sociais e ecológicos, o que implica também repensar a forma de organização politica a nível local, regional e global. 0 grande desafio que brota de nossa epocalidade é fazer da justiça, entendida como a ordenação racional da livre convivência entre os seres humanos, o horizonte que possa reger nossas ações e as instituições de uma sociedade em processo de mundialização.

nidade de destino sóbre esta nossa nave espacial chamada Terra [...]. E aqui se coloca a questão se não pode existir-se não deve existir - um mínimo de valores, normas e atitudes que sejam comuns a todos os homens. Portanto, um consenso ético minimo". 